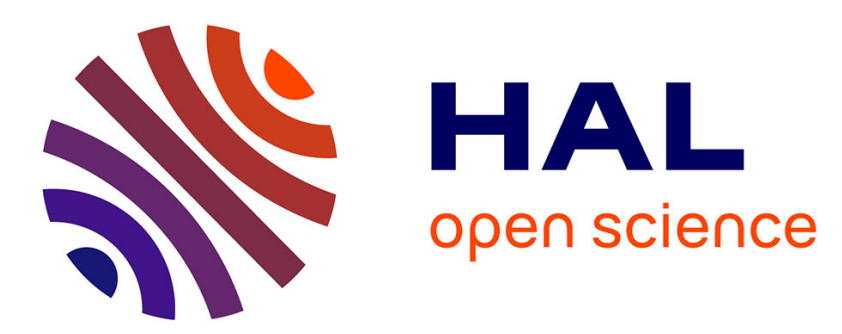

\title{
Occupational health and valid work exposure tools are keys to improving the health of ageing workers
}

Alexis Descatha, Yves Roquelaure

\section{To cite this version:}

Alexis Descatha, Yves Roquelaure. Occupational health and valid work exposure tools are keys to improving the health of ageing workers. Occupational and Environmental Medicine, 2018, 75 (5), pp.398-398. 10.1136/oemed-2017-104673 . hal-01870057

\section{HAL Id: hal-01870057 \\ https://hal-univ-rennes1.archives-ouvertes.fr/hal-01870057}

Submitted on 6 Feb 2020

HAL is a multi-disciplinary open access archive for the deposit and dissemination of scientific research documents, whether they are published or not. The documents may come from teaching and research institutions in France or abroad, or from public or private research centers.
L'archive ouverte pluridisciplinaire HAL, est destinée au dépôt et à la diffusion de documents scientifiques de niveau recherche, publiés ou non, émanant des établissements d'enseignement et de recherche français ou étrangers, des laboratoires publics ou privés. 


\section{Occupational health and valid work exposure tools are keys to improving the health of ageing workers}

Alexis Descatha 1,2; Yves Roquelaure 3

1. Versailles St-Quentin University, INSERM, UMS 011, UMR-S 1168, Villejuif, France

2. AP-HP (Paris Hospital “Assistance Publique Hôpitaux de Paris”), Occupational Health Unit, University hospital of West Suburb of Paris, Poincaré site, Garches, France

3. INSERM, U1085, IRSET, ESTER Team, University of Angers, Angers

Address for reprints: Prof. Alexis Descatha, Unité de santé professionnelle, AP-HP UVSQ, CHU Poincaré, 104 bd Poincaré, 92380 Garches, France

Tel: +33 (1) 471077 64; Fax: +33 (1) 471077 68; email: alexis.descatha@inserm.fr

\section{Word count 586 words, 15 references.}

Keywords public health; economy; occupational; retirement; work; job exposure matrix; prevention

No conflict of interest. We have read and understood the BMJ Group policy on declaration of interests and declare the following interests:

In addition to our supportive institution, Alexis Descatha is also paid by Elsevier Masson as editor-in-chief of the journal "Les archives des maladies professionnelles et de

l'environnement".

The Corresponding Author has the right to grant on behalf of all authors and does grant on behalf of all authors, a worldwide licence

(http://www.bmj.com/sites/default/files/BMJ\%20Author\%20Licence\%20March\%202013.doc) to the Publishers and its licensees in perpetuity, in all forms, formats and media (whether known now or created in the future), to i) publish, reproduce, distribute, display and store the Contribution, ii) translate the Contribution into other languages, create adaptations, reprints, include within collections and create summaries, extracts and/or, abstracts of the Contribution and convert or allow conversion into any format including without limitation audio, iii) create any other derivative work(s) based in whole or part on the on the Contribution, iv) to exploit all subsidiary rights to exploit all subsidiary rights that currently exist or as may exist in the future in the Contribution, v) the inclusion of electronic links from the Contribution to third party material where-ever it may be located; and, vi) licence any third party to do any or all of the above. All research articles will be made available on an Open Access basis (with authors being asked to pay an open access fee - see http://www.bmj.com/about-bmj/resources-authors/forms-policies-and-checklists/copyright-open-access-andpermission-reuse). The terms of such Open Access shall be governed by a Creative Commons licence-details as to which Creative Commons licence will apply to the research article are set out in our worldwide licence referred to above

Both authors have participated in writing the letter and approved it. 
Many countries have increased the legal retirement age due to economic constraints and aging populations.[1] One important obstacle to raising retirement age is premature aging caused by difficult and arduous working conditions.[2,3] Nevertheless, even for some countries with retirement ages that may vary according to working conditions, it is particularly challenging to define an optimal retirement age that consistently and fairly determines which workers may be granted earlier retirement due to difficult working conditions.

France started by defining exposures in terms of their consequences, i.e. the presence of a specific recognised occupational disease or injury.[4] In 2014, the Government introduced a new rule requiring employers to evaluate the extent of workers' exposures to multiple working conditions. The workers could retire earlier depending on the number of years of such exposure. The decision was based on the number of years of exposure to physical risks (carrying heavy loads, awkward postures, vibrations, hyperbaric exposures, noises, and extreme temperatures), chemical risks (carcinogenics hazards) and organizational risks (mechanically paced tasks, night work, rotating shifts).[5] These were evaluated at an individual level with collective guidance for certain groups of workers. Then, premature aging was considered and retirement might occur earlier. However, this new rule is very difficult to apply for most employers responsible for declaring exposure annually for each worker. The new French government has decided that biomechanical and chemical exposure will be deleted from the definition of exposure leading to early retirement (remaining exposures are night work, rotating shifts, mechanically paced tasks, and hyperbaric work).

However, some simple tools have been developed to help employers and social benefit managers to accurately and consistently assess worker exposures, such as job-exposure matrices (which estimate multiple exposures based on population values for individual job 
titles). Theses matrices might have real benefit when used by occupational professionals in order to focus employer attention on jobs at high risk for premature aging. Such tools might also be useful to consistently and fairly guide social insurance decisions, such as eligibility for early retirement, where workplace exposures over time are a main factor in the decisions made by occupational health teams.[6]

Efforts to reduce relevant exposures closely involve occupational health teams, including occupational physicians and nurses, and exposure specialists (hygienists, ergonomists, psychologists). In fact, all employers in France (with the exception of self-employed workers) have an occupational health team coordinated by occupational physicians for all of their employees.[7] The core job of these practitioners is occupational risk assessment and related prevention of work-related disorders.[8] In addition, job exposure matrices are decision tools that can be used and applied appropriately by our occupational health practitioners, to improve the general health of the work task force. For instance, occupational practitioners at small companies will benefit from using these job exposure matrices to screen difficult work conditions, such as mechanically paced tasks or other arduous working practices related to premature aging, and can use their expertise for more complicated situations.[9] Other tools exist for difficult and arduous working condition assessment by occupational practitioners: decision rules based on a questionnaire, specific tools for specific working conditions (e.g. welding activities, shift work,..) and multidisciplinary tools used by the whole team. [10-13]

In conclusion, we feel occupational health teams and valid decision tools are keystones for improving health of aging workers. This applies to our own country, which has a particularly high level of coverage of occupational health practitioners compared to other countries, but 
improving occupational health access for workers and related questions is important everywhere.[14,15]

\section{Acknowledgements}

We would like to thank Richard Carter for helping us to improve the language of this document.

\section{References}

1 Descatha A, Cyr D, Mediouni Z, et al. Work-related premature ageing: old concept but emerging stakes. Occup Environ Med 2013;70:675. doi:10.1136/oemed-2013-101618

2 Burdorf A. Is early retirement good for your health? BMJ 2010;341:c6089.

3 Burdorf A A, Järvholm B, Härmä M. The importance of preventing work-related disability. Scand J Work Environ Health 2014;40:331-3. doi:10.5271/sjweh.3439

4 Descatha A, Duval S, Sabbath E, et al. Difficult working conditions, retirement, and reform in France: what are the roles of the medical social worker and primary care physician? Health Soc Work 2012;37:55-7.

5 Fantoni-Quinton S. The personal account for prevention of arduous work. Arch Mal Prof Environ 2015;76:352-4. doi:10.1016/j.admp.2015.05.003

6 Kerbrat J, Descatha A. The recognition of health consequences of difficult working conditions in France and its evaluation with the use of a job-exposure matrix. ArchMalProf 2017;79:Online.

7 Rantanen J, Lehtinen S, Iavicoli S. Occupational health services in selected International Commission on Occupational Health (ICOH) member countries. Scand J Work Environ Health 2013;39:212-6. doi:10.5271/sjweh.3317

8 Frimat P, Fantoni-Quinton S. Santé travail : une nouvelle dynamique ? Arch Mal Prof Environ 2014;75:469. doi:10.1016/j.admp.2014.07.003

9 Malchaire JB. The SOBANE risk management strategy and the Déparis method for the participatory screening of the risks. Int Arch Occup Environ Health 2004;77:443-50. doi:10.1007/s00420-004-0524-3

10 Descatha A, Herquelot E, Carton M, et al. Is physically arduous work associated with limitations after retirement? Findings from the GAZEL cohort. Occup Environ Med 2016;73:183-6. doi:10.1136/oemed-2015-103130

11 Amiard V, Libert J-P. What are the criteria for difficult working conditions during shift work? Arch Mal Prof Environ 2015;76:292-301. doi:10.1016/j.admp.2015.02.006 
12 Lucas D, Le Gall A, Capellmann P, et al. Cardiac assessment in a population of ship repairing welders. Arch Mal Prof Environ 2017;78:231-8. doi:10.1016/j.admp.2016.09.010

13 Bernard N, Bonami J, Gagnant B. Multidisciplinary tool for difficult arduous work assessment. Arch Mal Prof Environ 2014;75:S27. doi:10.1016/j.admp.2014.03.087

14 Raynal A. Occupational medicine is in demise. BMJ 2015;351:h5905.

15 Rantanen J, Lehtinen S, Valenti A, et al. A global survey on occupational health services in selected international commission on occupational health (ICOH) member countries.

BMC Public Health 2017;17:787. doi:10.1186/s12889-017-4800-z 